\title{
Employee Retention in Job Stress and Leadership Style Perspective Mediated by Job Satisfaction
}

\author{
Justine Tanuwijaya ${ }^{1}$, Jakaria ${ }^{2}$ \\ \{justine@trisakti.ac.id ${ }^{1}$, jakaria.fe@trisakti.ac.id² \\ Faculty of Economics and Business, Universitas Trisakti ${ }^{1,2}$
}

\begin{abstract}
This study aims to investifate the effect of job stress and leadership style (transformational and toxic) on job satisfaction and its impact on employee retention. The research design uses hypothesis testing. The population were employees of the Faculty of Economics and Business, Universitas Trisakti. The number of samples is 154 respondents. The analytical method is the Structural Equation Model (SEM). The research findings showed that even though job stress produces a negative influence on job satisfaction, it is not statistically significant. Leadership styles have a positive effect on job satisfaction, where transformational leadership is more dominant than toxic leadership. The results also showed that job satisfaction has a positive impact on employee retention. The indirect test results showed that job satisfaction mediated for job stress but not mediated for leadership style where the effect of transformational leadership is stronger than toxic leadership.
\end{abstract}

Keywords: Job stress; transformational leadership; toxic leadership; job satisfaction; employee retention

\section{Introduction}

In the company's sustainable business processes, employees have an important role. In organizations, competitive advantage is determined and influenced by human resources. Generally, employees participate in creating new innovations that lead to the success and profitability of a company. When an employee leaves an organization, he or she will take the knowledge, experience, culture and values gained, and can be misused to attack the old organization.

Job stress is something that organizations need to pay attention to. Job stress will affect the response of employees. The most thing to avoid is that in the end employees will feel dissatisfied with their work. Job stress can occur due to a lack of communication between employees and superiors, resulting in conflicts and causing job stress [1]

Another factor that affects on job satisfaction is leadership style. [2] stated that leadership style greatly affects job satisfaction. In recent years, transformational leadership is the most studied leadership concept in organizational behavior and management. Transformational leadership displays how a leader puts his personal interests aside and inspires employees to adopt the values and goals of the company. Transformational leaders inspire their employees through a strong vision and mission, optimism, enthusiasm, and emotional appeal. Leaders 
with a strong vision and mission tend to have followers who perceive tasks as a challenge, interesting, and important so they set higher standards of performance. [3] said that transformational leadership styles are found effective, because they encourage creativity in organizations.

So far, leadership theory has always focused on the positive side. But in reality, there are several types of bad leadership. This type of leadership is an example of being unproductive in an organization. For example, a leader who has destructive behavior and exhibits behavior that can cause harm to others, either emotionally or physically. This is called toxic leadership. Examples are blaming subordinates for a mistake excessively, demands for work that are unreasonable, insulting employees' work abilities and others. Generally these leaders will prioritize the work interests of employees and others. Generally these leaders will prioritize personal interests over organizational interests. This is considered to have a negative effect on the organizational environment [4]. This study attempts to combine the types of leadership, both from the perspective of leadership theory which has always focused on the positive side (transformational leadership) with the bad type of leadership (toxic leadership).

Satisfied workers will generally keep a good retention of their work. According to research by [5], job satisfaction is also considered to have a relationship with the bond created between employees and the organization. Employee retention is very useful for both parties, namely the organization and employees. Keeping employees working for the organization for a long time is not easy and affects the success of the organization. According to [6], over time, it is easier for people to change jobs. Based on the above explanation research was conducted to focus on the problem of employee retention in relation to job satisfaction that occurs due to the influence of job stress and leadership style, both transformational and toxic leadership.

\section{Theoretical Review}

\subsection{Job Stress}

The term of job stress is a negative reaction to physical or emotional responses that happen when job requirements exceed the capabilities of employees. This not only has an impact on health, but also damages the performance of employees [7]. There are three main components of job stress, namely stimulus, response, and interaction. Stimulus is the cause of stress, whether it comes from many aspects. The response is presented by the individual as anxiety. The connection between stimulus and response is said as interaction [8]. According to [9], there are several factors that affect job stress, for example:

1. Job dissatisfaction and poor performance

2. Poor employee relations

3. Unsupportive family

4. Lack of self-confidence

5. Role ambiguity (lack of clarity on responsibilities)

6. Lack of human resources and opportunities to improve performance

7. Long working time

8. Unsatisfactory income

9. Excessive workload

\subsection{Leadership Sytle}




\section{a) Transformational Leadership}

Leadership is a someone's personal ability to influence others to do something that is acceptable to his followers and has the ability to put himself or herself in any situation. [10]. Leadership is defined as a process of social influence that can increase the efforts of others to achieve an organization's goals. Leadership is needed to achieve goals, motivate employees and monitor employee performance [11]. Transformational leadership directs to a benefial relationship with encouragement, performance, employee engagement, and effectiveness of management [12].

Balwant (2017) defines transformational leadership as a visionary-focused leader with behaviors that reflect the vision of an organization positively and encourage its members to achieve goals that are aligned with the vision through a model for creative problem solving, and demonstrate concern for the individual needs of its members., as well as providing rewards when organizational goals have been achieved. According to [12], transformational leader will present an obvious organizational dream and encourage employees to work according to the organization's vision and mission, as well as contributing to provide maximum results for the organization. Thus it can be concluded as a means to achieve prosperity and company goals by motivating and helping employees to develop their potential in job based on the company's vision and mission.

\section{b) Toxic Leadership}

So far, leadership theory focuses only on the positive side and leads to a leadership bias. But it turns out that there is a bad type of leadership. This is one example that shows unproductive behavior in organizations [1]. Dr. Marcia Lynn Whicker, the first person who introducedand discussed this on leadership styles in the workplace, namely trustworthiness, transition, and toxic [14].

One of the first to pioneer research on toxic leadership was Lipman Blumen, who described it as a process by which leaders, because of their bad behavior or personal character, cause serious harm to followers and organizations. Their strong personality can cover bad goals in the short term, but their bad personality will affect individuals and organizations in the long term [15]. Some examples of things that are done, for example, these leaders differentiate behavior towards employees, limiting productive interactions that occur between employees. In addition, this leader will criticize employees in a condescending style and give a subjective assessment of the abilities and work of their subordinates [16].

\section{c) Job Satisfaction}

Job satisfaction is one element that acts in the success of a company. To survey employees' job satisfaction is a difficult thing, because job satisfaction is very broad and changing. This can be influenced by many factors. However, in general, organizations often use surveys to measure the level of employee satisfaction. For smaller organizations, surveys can be conducted face-to-face [17]. There are several factors for creating job satisfaction [18]:

1. Satisfaction and appreciation and recognition, It is one of the factors that really plays a role, which inspires employees to do their best work to achieve results. An award is assessed as something that is given as an appreciation for what has been done.

2. Employee satisfaction and involvement in decision making, having an influence on job satisfaction, decision making can be done formally or informally and involves intellectual, 
emotional and physical involvement of employees, so that they feel are valued for their opinions.

3. Satisfaction and work environment atmosphere, the atmosphere and work environment also have a role in job satisfaction. This includes ventilation, lighting, and other environmental factors.

4. Employee satisfaction and empowerment, with the high level of competition, generally employee empowerment is also one of the things that organizations pay attention to. Empowerment here includes providing freedom for employees to make decisions in carrying out daily activities.

It is developed through evaluative assessments, affective experiences at work and beliefs about work. Therefore, job satisfaction is a response shown by employees to their organization [14].

\section{d) Employee Retention}

Employee retention is one of the challenges for organizations. Employee retention is an effort made with the aim of keeping employees working at the company for the maximum period [19]. One of the important things in employee retention is social identification, which in this case is the perception of belonging and being united with the organization [20]. The main goal of employee retention is to prevent employees from leaving the organization. This is essential to keep the organization productive and running on purpose.

\subsection{Previous Empirical Studies}

\section{a) Relationship between Job Stress and Job Satisfaction}

[21] exhibited a significant impact of job stress on performance and job satisfaction. [22] also denoted that job stress has an influence on job satisfaction. This is according to study of [5] which indicated that two variables have a significant negative relationship, where if the level of job satisfaction is high, then the level of job stress is low.

\section{b) Relationship between Leadership Style and Job satisfaction}

[23] in his research found that transactional and transformational leadership and employee trust in leaders have a positive correlation to employee job satisfaction. Aube (2015) in his research also found that the all five dimensions of transformational leadership had a significant linkage. This result is also supported by the findings of [25] and [26]. Research conducted by [27] stated that toxic leadership has a significant effect on job satisfaction. This promoted [4] which showed that toxic leadership has an influence on job satisfaction.

\section{c) Relationship Between Job Satisfaction and Employee Retention}

Research conducted by [28] ound that link between job satisfaction and employee retention is significant. This is in accordance with the research conducted by [29] with the results that job satisfaction and employee retention have a positive correlation. Research by [30] stated the same.

\subsection{Conceptual Framework}


Crystallization from literature review and empirical studies as described above produces a conceptual framework as shown in the following chart.

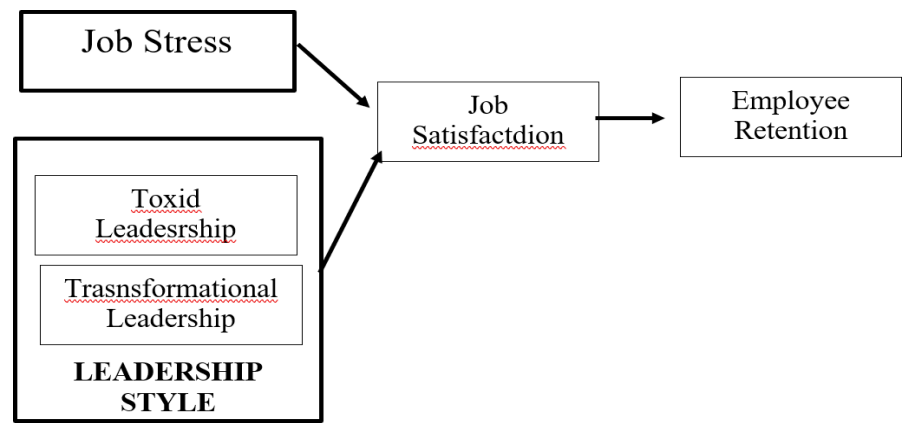

Fig. 1. Research Conceptual Framework

\subsection{Research Hypothesis}

Employees who experience stress at work will affect their job satisfaction. A number of studies support the negative impact of job stress on job satisfaction, including [21], [22] and [5]. Based on this, the hypotheses proposed are:

$\mathrm{H} 1$ : Job stress has negative effect on job satisfacton

Job satisfaction is also determined by how a company leader directs employees to work optimally to achieve the determined company goals in accordance with the vision and mission ([23], [25], and [26]). Otherwise, a toxic leader give a negative influence on employee job satisfaction because employees feel they are being treated inappropriately. [27] and [4] supported the same results. Based on the explanation above, the hypothesis proposed in this study are:

H2 : Leadership sytle (transformational dan toxic leadership) have a positive on job satisfaction

Employee job satisfaction will have consequences for employees to keep working at the company and of course in the long term will affect the operational sustainability of the company. [28], [30], and [29] expressed that there is a prominent linkage between job satisfaction and employee retention. The hypothesis proposed in the study are:

H3 : Job satisfaction has a positive effect on employee retention

Hypothesis 1 declares that job stress and job satisfaction have a negative influence and hypothesis 3 expresses that job satisfaction has a positive effect on employee retention. The hypothesis proposed in this study is:

H4 : Job satisfaction mediates the negative effect of job stress on employee retention.

Hypothesis 2 claims that leadership style has a positive impact on job satisfaction and hypothesis 3 reveals that job satisfaction has a positive leverage on employee retention. The hypothesis proposed in this study is:

H5 : Job satisfaction mediates the positive influence of leadership style on employee retention.

\section{Research Methodology}




\subsection{Research Design}

This study used hypothesis testing, which aims to verify the effect of job stress, transformational leadership, toxic leadership, job satisfaction, and its impact on employee retention. Data taken based on time using cross sectional, that is data taken only in a certain period of time. The unit of analysis in this research is employees, both lecturers and supporting staff of the Faculty of Economics and Business, Universitas Trisakti (FEB Usakti).

\subsection{Variable and Measurement}

The research variables used consist of independent variables (job stress and leadership style), mediating variables (job satisfaction), and dependent variables (employee retention). Job stress is measured using indicators adapted from [31]. Leadership styles include transformational and toxic leadership. To measure transformational leadership used indicators adapted from Pasha et al., (2017), while for toxic leadership using indicators adapted from [33]. Measurement of job satisfaction using a statement adapted from [34]. The employee retention variable is measured using a statement adapted from [35]. All research variables are interval scale and measured with a 5-point Likert scale, range from strongly disagree to strongly agree.

\subsection{Population and Sample}

In this study, the population used were employees from FEB Usakti Trisakti, both for permanent lecturers and supporting staff. The minimum number of samples used in accordance with Hair et al., (2011) is $5 \mathrm{x}$ the number of indicators used in the study so that the total sample used is 24 indicators in the SEM model x $5=120$ respondents. This study uses a sample of 154 respondents, thus meeting the minimum requirements sample.

\subsection{Analysis Method}

The analytical method used consists of: Research Instrument Testing (Validity and Reliability Testing). Testing the research instrument is the validity and reliability testing. Validity testing is carried out to test whether the measurement indicators used are valid (measures what you want to measure) with factor loading criteria where with a total sample of 154 , an indicator is said to be valid if it has a factor loading $>0.45$. Reliability testing is done using Cronbach Alpha where an indicator is said to be reliable if it has a Cronbach Alpha value $>0.6$ [36]. The results of the processing show that all of the indicators used, only 1 indicator that is not valid, namely one indicator of the unappreciativeness dimension of the toxic leadership variable because it produces a factor loading value of $<0.45$ while the other indicators are valid and reliable. More details can be observed in table 1.

Table 1. Validity and Reliability Testing of Research Variables.

\begin{tabular}{lcc}
\hline \multicolumn{1}{c}{ Variable } & Number of Indicators & Valid and Reliable Indicator \\
\hline Job Stress & 9 & 9 \\
Transformational Leadership & 7 & 7 \\
Toxic Leadership & 11 & 10 \\
a. Unapprecitiveness dimension & & \\
b. Self-interest dimension & 9 & 9 \\
c. Selfishness dimension & & \\
\hline
\end{tabular}




\begin{tabular}{ccc}
\hline \multicolumn{1}{c}{ Variable } & Number of Indicators & Valid and Reliable Indicator \\
\hline d. Negative spiritual state dimension & 5 & 5 \\
& 5 & 5 \\
Job Satisfaction & 8 & 8 \\
Employee Retention & 4 & 4 \\
\hline Source: data processed &
\end{tabular}

Hypothesis testing is using the Structural Equation Model (SEM) which is carried out in stages:

\section{a) Theoretical Model Development}

The SEM model was obtained as shown in Figure 2. The number of samples was limited in the study while the indicators used in the study were relatively large, so there was a revision of the research model, especially for the leadership variable, in which the variables used are adjusted, namely leadership style, where the formation consists of transformational and toxic leadership.

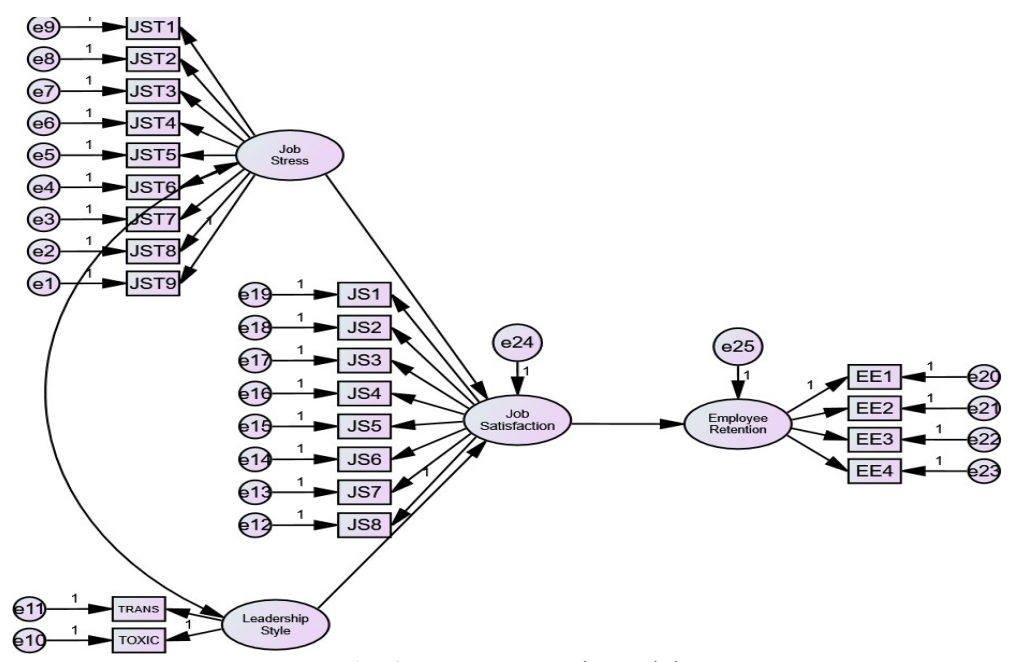

Fig. 2. SEM Research Model

\section{b) Model Transformation in the Regression Equation Model}

Based on the SEM model framework that has been proposed previously, the regression equation model used is stated as follows:

1. Model 1: Job Satisfaction $=\alpha_{1}$ Job Stress $+\alpha_{2}$ Leadership Style $+\varepsilon 1$

2. Model 2: Employee Retention $=\beta 1$ Job Satisfaction $+\varepsilon 2$

\section{c) Perform Model Fit Testing}

Testing the suitability of the model (model fit) is a test that must be carried out as a prerequisite before testing the research hypothesis. From a number of model fit testing criteria, a number of model fit indicators were selected. The test results for the fit model are shown in 
table 2. The processing results for the fit model showed:

Table 2. Model Fit Test Indicator

\begin{tabular}{|c|c|c|c|c|}
\hline Measurement Type & Measurement & $\begin{array}{l}\text { Fit Model } \\
\text { Decisions }\end{array}$ & $\begin{array}{l}\text { Processed } \\
\text { Results } \\
\end{array}$ & Decision \\
\hline \multirow[t]{4}{*}{ Absolute fitmeasures } & Chi-square & low Chi Square & 494.94 & \\
\hline & $\begin{array}{l}\text { p-value Chi- } \\
\text { Square }\end{array}$ & $\geq 0.05$ & 0.0000 & Poor fit \\
\hline & RMSEA & $\leq 0.10$ & 0.0893 & Model Fit \\
\hline & GFI & $\geq 0.90$ & 0.7730 & Poor fit \\
\hline \multirow{5}{*}{$\begin{array}{c}\text { Incrementalfit } \\
\text { measures }\end{array}$} & RMR & $-4.0<x>4.0$ & 0.0869 & Model fit \\
\hline & NFI & $\geq 0.90$ & 0.7628 & Poor fit \\
\hline & IFI & $\geq 0.90$ & 0.8540 & $\begin{array}{c}\text { Marginal } \\
\text { fit }\end{array}$ \\
\hline & RFI & $\geq 0.90$ & 0.7308 & Poor fit \\
\hline & CFI & $\geq 0.90$ & 0.8517 & $\begin{array}{c}\text { Marginal } \\
\text { fit }\end{array}$ \\
\hline $\begin{array}{c}\text { Parsimoniusfit } \\
\text { meassure }\end{array}$ & CMIN/DF & Antara 1 sampai 5 & 2.2195 & Model fit \\
\hline
\end{tabular}

The information from the table showed that of the 9 fit model indicators used, 3 indicators resulted in a model fit conclusion, namely the RMSEA, RMR, and CMIN/DF indicators. A total of 2 indicators resulted in a marginal fit model conclusion, namely for the IFI and CFI indicators and 4 other indicators resulted in an unfit model conclusion, namely for the p-value of chisquare, GFI, NFI and RFI. These findings indicate that theoretical hypothesis testing can be continued.

\section{Results and Discussion}

\subsection{Descriptive Statistics of Research Variables}

The descriptive statistical processing of job stress variables are shown in table 3 . Information from the table produces an average value of 2.827 , which means that respondents do not experience too much stress in carrying out their work. The standard deviation value of 0.788 indicates the variation of respondents' answers for the job stress variable is quite homogeneous, which is in the range of answers between 2 to 3 .

For leadership style, respondents considered that toxic leadership was responded quite well. With an average value of 3.614 and a standard deviation of 0.793 , it shows that the toxic leadership characteristics of leaders at FEB Universitas Trisakti are not too dominant. The response to transformational leadership also resulted in a fairly good response as indicated by the average value of respondents' answers of 3.525 with a standard deviation of 0.839 .

Job satisfaction received during work produced mean value of respondents' answers of 3,474 . This shows that employees feel quite a job satisfaction. The standard deviation value of 0.676 indicates that the majority of respondents' answers to the job satisfaction variable are in the range of answers between 3 and 4 .

For descriptive statistics on employee retention variables, overall respondents gave quite good responses with the mean value of respondents' answers of 3,435, where that employees have a fairly high desire to remain. The standard deviation value of 0.797 indicates that the 
majority of respondents' answers to the employee retention variable are in the range of answers between 3 and 4 .

Table 3. Descriptive Statistics of Research Variables

\begin{tabular}{lcccc}
\hline \multicolumn{1}{c}{ Variable } & Mean & Std. Deviation & Minimum & Maximum \\
\hline Job Stress & 2.827 & 0.788 & 1.00 & 4.78 \\
Transformational Leadership & 3.525 & 0.839 & 1.00 & 5.00 \\
Toxic Leadership & 3.614 & 0.793 & 1.02 & 5.00 \\
Job Satistaction & 3.474 & 0.677 & 1.38 & 4.88 \\
Employee Retention & 3.435 & 0.797 & 1.00 & 5.00 \\
\hline
\end{tabular}

Source: Data processed

\subsection{Analysis and Discussion}

\section{a) Analysis of Findings}

From the testing results of research hypothesis, there were 2 hypothesis that are not supported, namely hypothesis 1 and hypothesis 4 . The results of testing hypothesis 1 produce an estimated coefficient value of -0.005 , indicated that increasing job stress will decrease job satisfaction and vice versa, decreasing job stress will increase job satisfaction. These findings explained that the proposed theoretical hypothesis is appropriate. With a p-value of $0.477>$ 0.05 . The hypothesis is not supported. The hypothesis 4 test are indicated by the estimated coefficient value of -0.002 , which means that increasing job stress will reduce employee retention with job satisfaction as mediation and conversely decreasing job stress will increase employee retention with job satisfaction as mediation. With the $\mathrm{p}$-value of the $\mathrm{t}$ statistic of $0.477>0.05$, Ho is not accepted, so the hypothesis is not supported.

From table 4 it can be seen that the hypothesis H2, H3, and H5 were supported. For H2, the processing results showed the estimated coefficient value of 1.651 , which means that increasing leadership style will increase job satisfaction and vice versa, decreasing leadership style will decrease job satisfaction. The t-statistical value of 5.369 resulted in a p-value of $0.000<0.05$, so it can be told that the positive impact of leadership style on job satisfaction was proved significant. Likewise with the $\mathrm{H} 3$ test, from the processing results, it is shown that the estimated coefficient value was 0.567 , which means that increasing leadership style will increase job satisfaction and conversely decreasing leadership style will decrease job satisfaction. So it can be said that their positive influence was significant. Finally is H5 test. From the processing results, the estimated coefficient value is 0.936 , which means that increasing leadership style will increase employee retention with job satisfaction as mediation and conversely decreasing leadership style will decrease employee retention with job satisfaction as mediation. The p-value of the $t$ statistic of $0.000<0.05$, so that the hypothesis supported.

Table 4. Research Hypothesis Testing Results

\begin{tabular}{clcccc}
\hline H1 & $\begin{array}{l}\text { There is a negative effect of job stress on job } \\
\text { satisfaction }\end{array}$ & -0.005 & -0.055 & 0.477 & $\begin{array}{c}\text { Estimate } \\
\text { C.R. }\end{array}$ \\
H2 & $\begin{array}{l}\text { There is a positive effect of leadership style on } \\
\text { supported } \\
\text { job satisfaction }\end{array}$ & 1.651 & 5.369 & 0,000 & Supported \\
H3 & $\begin{array}{l}\text { There is a positive effect of job satisfaction on } \\
\text { employee retention }\end{array}$ & 0567 & 8,036 & 0,000 & Supported \\
\hline
\end{tabular}




\begin{tabular}{lllllc}
\hline H4 & $\begin{array}{l}\text { Job satisfaction mediates the negative effect of job } \\
\text { stress on employee retention }\end{array}$ & $-0,002$ & $-0,055$ & 0,477 & $\begin{array}{c}\text { Not } \\
\text { supported } \\
\text { H5 }\end{array}$ \\
$\begin{array}{l}\text { Job satisfaction mediates the positive effect of } \\
\text { leadership style on employee retention }\end{array}$ & 0,936 & 4,440 & 0,000 & Supported \\
\hline
\end{tabular}

Source: Data Processing Results

\section{b) Discussion}

The research findings show hypothesis 1 which states that job stress has no negative effect on job satisfaction for employees at the Faculty of Economic and Business, Universitas Trisakti. Many factors are the reasons for not supporting hypothesis 1 , namely:

1. The majority of respondents are women, which is $62.3 \%$. If it is related to the division of tasks in the household, especially in Indonesia, the man is the head of the household who has the main task of providing for his family. If a wife works in general, they only help to strengthen the family economy so that the motivation to pursue a career is not as big as male employees and this is main cause why job stress has no significant negative influence on job satisfaction.

2. Based on the age group, most of the respondents are above 50 years old, reaching a figure of $51.9 \%$, which means that they are senior employees who have a relatively long working period. This shows that having a high service period can implicitly mean that job stress felt by employees does not have significant effect on employees' satisfaction

3. Most of respondents are lecturers, is $75.6 \%$, reinforcing the insignificant negative weight of job stress on job satisfaction. The workload of a lecturer is significantly different from the workload of supporting staff, where a lecturer only has 9 credits per week, which is equivalent to 3 courses with 3 credits each. If a lecturer conducts research, the teaching load is reduced to 6 credits. If the obligations imposed are fulfilled, a lecturer is allowed to carry out activities outside the campus, for example as a professional consultant for companies or as instructors in companies through providing training to company employees according to company needs. Activities like this, of course, provide income for the lecturers concerned in addition to the regular income received from the FEB Usakti institution. The age of the lecturers who are included in the group of senior lecturers with a relatively long tenure strengthens the evidence that the negative effect of them is not proven.

The second hypothesis finding indicated that leadership style has a positive leverage on job satisfaction. When viewed from the dominant type of leadership that occurs at FEB Usakti, it shows that transformational leadership is stronger than toxic leadership. This can be seen from the contribution of the transformational leadership coefficient which is greater than toxic leadership. This result can be seen from the value of the estimated coefficient for the contribution of transformational leadership of 0.9331 while for toxic leadership it has a contribution coefficient of 0.4945 . These results indicated that the characteristics of a transformational leader are more needed by employees in providing work motivation compared to the character of a toxic leader who always looks for and reveals mistakes made by employees without looking for solutions to fix mistakes so that in the future it will be better.

Hypothesis 3 represented that job satisfaction has a positive effect on the intention of employees to keep working at the institution. By referring to the findings of hypothesis 1 and 2 , it is concluded that job satisfaction can mediate the positive impact of leadership style on employee retention, while job satisfaction is not a mediating variable for the effect of job 
stress on employee retention.

\section{Conclusion and Managerial Implications}

Job stress experienced by FEB Usakti employees, both lecturers and teaching staff, had no significant impression on job satisfaction. The leadership style has a significant effect on job satisfaction, where transformational leadership has a positive effect, while toxic leadership has an opposite one. Increased job satisfaction has an impact on employees' decisions to keep working at the organization. The indirect effect test results show that job satisfaction does not mediate the negative influence of job stress on employee retention. Job satisfaction is a variable that is proven to mediate the positive influence of leadership style which consists of transformational leadership and toxic leadership.

The managerial implication that can be given from the results of this study is the faculty must continue to strive to increase employee job satisfaction through several activities, including faculty gatherings which have been an annual agenda as. one way to increase employee motivation at work. Increased capacity building in shaping the character of employees who have high productivity is always carried out, for example through training aimed at finding new innovations in an effort to increase employee productivity. In addition, the leadership style desired by FEB Usakti employees is transformational leadership compared to toxic leadership, so the transformational type of FEB Usakti leader must always be improved from time to time and minimize the nature of a toxic leader.

\section{References}

[1] H. Zagross and Z. Jamileh, "Relationship between Toxic Leadership and Job Stress of Knowledge Workers," Stud. Bus. Econ., vol. 11, no. 3, pp. 84-89, 2016, doi: 10.1515/sbe-2016-0037.

[2] Y. Bagyo, "Engagement as a Variable to Improve the Relationship between Leadership, Organizational Culture on the Performance of Employees," IOSR J. Bus. Manag., vol. 14, no. 4, pp. 1-8, 2013, doi: 10.9790/487x-1440108.

[3] S. A. Eisenbeiss, D. van Knippenberg, and S. Boerner, "Transformational Leadership and Team Innovation: Integrating Team Climate Principles," J. Appl. Psychol., vol. 93, no. 6 , pp. 1438-1446, 2008.

[4] I. Uysal, "The Mediation Role of Toxic Leadership in the Effect of Job Stress on Job Satisfaction.," Int. J. Bus., vol. 24, no. 1, pp. 56-76, 2019.

[5] S. Bemana, H. Moradi, M. Ghasemi, and S. M. Taghavi, "The Relationship among Job Stress and Job Satisfaction in Municipality Personnel in Iran,” World Appl. Sci. J., vol. 22, no. 2, pp. 233-238, 2013.

[6] Y. Mandhanya, "a Study of Impact of Working Environment on Retention of Emplotees (With special reference to Automobile sector)," Glob. Manag. Rev., vol. 9, no. 4, pp. 116-128, 2015.

[7] E. Ekienabor, "Impact of Job Stress on Employees' Productivity and Commitment," Int. J. Res. Business, Manag. Account., vol. 2, no. 5, pp. 124-133, 2016.

[8] M. N. Gharib, S. A. Jamil, M. Ahmad, and S. Ghouse, "The Impact of Job Stress on Job Performance: A case Study on Academic Staff at Dhofar University," Int. J. Econ. Res., vol. 13, no. 1, pp. 21-33, 2016. 
[9] R. H. Burman and T. G. Goswami, "A Systematic Literature Review of Work Stress," Int. J. Manag., vol. 5, no. 3, pp. 112-132, 2018.

[10] U. Triyono, Kepemimpinan Transformasional dalam Pendidikan Formal, non Formal, dan Infromal. Yogjakarta: Deepublish, 2019.

[11] S. H. Almaki, A. D. Silong, K. Idris, and N. W. Abd. Wahat, "Understanding of the Meaning of Leadership from the Perspective of Muslim Women Academic Leaders," $J$. Educ. Soc. Res., vol. 6, no. 2, pp. 225-236, 2016, doi: 10.5901/jesr.2016.v6n2p225.

[12] R. Masa'deh, B. Y. Obeidat, and A. Tarhini, "A Jordanian Empirical Study of the Associations Among Transformational Leadership, Transactional Leadership, Knowledge Sharing, Job Performance, and Firm Performance: A Structural Equation Modelling Approach," J. Manag. Dev., vol. 35, no. 5, pp. 681-705, 2016.

[13] P. T. Balwant, "Stay Close! Leader Distance, Transformational Leadership, Engagement, and Performance in Teams," Acad. Manag. Proc., p. No.1, 2017.

[14] N. Singh, S. Sengupta, and S. Dev, "Dark Sides of Organizational Behavior and Leadership: Toxic Leadership," in The Most Menacing Form of Leadership, 2018, pp. $147-164$.

[15] W. A. Burns, "A Descriptive Literature Review of Harmful Leadership Styles: Definitions, Commonalities, Measurements, Negative Impacts, and Ways to Improve These Harmful Leadership Styles," Creight. J. Interdiscip. Leadersh., vol. 3, no. 1, pp. 33-52, 2017.

[16] I. Milosevi, S. Maric, and D. Lončar, "Defeating the Toxic Boss: The Nature of Toxic Leadership and the Role of Followers Ivana Milosevic, Stefan Maric, Dragan Lončar Dragan Lončar," J. Leadersh. Organ. Stud., vol. 27, no. 2, pp. 117-137, 2019.

[17] T. Taskinen, "Employee job satisfaction in 21st Century organizations," 2019.

[18] L. N. Frempong, W. Agbenyo, and P. A. Darko, "The Impact of Job Satisfaction on Employees' Loyalty and Commitment: A Comparative Study Among Some Selected Sectors in Ghana," Eur. J. Bus. Manag., vol. 10, no. 12, pp. 95-105, 2018.

[19] N. R. A. S. S. Wijesiri, G. S. Paranagama, M. M. A. S. Sirirwardhana, D. L. N. C. Thilakarathna, R. . Weerarathna, and U. P. G. . Pathirana, "The Impact of HR Practices on Employee Retention; A Case of BPO Sector, Sri Lanka," Int. J. Hum. Resour. Stud., vol. 9, no. 1, pp. 1-21, 2019, doi: 10.5296/ijhrs.v9i1.14050.

[20] N. Steigenberger and N. Mirc, "Should I Stay or Should I Go? Multi-Focus Identification and Employee Retention in Post-Acquisition Integration," Hum. Relations, vol. 73, no. 3, pp. 981-1009, 2020.

[21] A. Hanafi, Zunaidah, and M. Ulfa, "The Effect of Job Stress Toward Employee Performance Through Job Satisfaction of PT Muara Alam Sejahtera Employees," Int. J. Sci. Res. Publ., vol. 8, no. 8, pp. 1-5, 2018, doi: 10.29322/ijsrp.8.8.2018.p8002.

[22] N. Hoboubi, A. Choobineh, F. Kamari Ghanavati, S. Keshavarzi, and A. Akbar Hosseini, "The Impact of Job Stress and Job Satisfaction on Workforce Productivity in an Iranian Petrochemical Industry," Saf. Health Work, vol. 8, no. 1, pp. 67-71, 2017, doi: 10.1016/j.shaw.2016.07.002.

[23] H. Asencio, "Leadership, Trust and Organizational Performance in The Public Sector," Transylvanian Rev. Adm. Sci., no. Special Issue, pp. 5-22, 2016.

[24] R. G. Aube, "Transformational Leadership as a Predictor of the Job Satisfaction of Millennials,” 2015.

[25] J.-L. M. Laglera, J. C. Collado, and J.-A. M. M. de Oca, "Effects of Leadership on Engineers: A Structural Equation Model,” Eng. Manag. J., vol. 25, no. 4, pp. 7-16, 2015 . 
[26] K. Rothfelder, M. C. Ottenbacher, and R. J. Harrington, "The Impact of Transformational, Transactional and non-Leadership Styles on Employee Job Satisfaction in the German Hospitality Industry," Tour. Hosp. Res., vol. 12, no. 4, pp. 201-214, 2012, doi: 10.1177/1467358413493636.

[27] W. A. Nafei, "The Impact of Toxic Leadership on Job Attitudes A Study on Teaching Hospitals in," Case Stud. J., vol. 8, no. 2, pp. 45-58, 2019.

[28] S. Salman, A. Mahmood, F. Aftab, and A. Mahmood, "Impact of Safety Health Environment on Employee Retention in Pharmaceutical Industry: Mediating Role of Job Satisfaction and Motivation,” J. Bus. Stud., vol. 12, no. 1, pp. 185-197, 2016, doi: 10.46745/ilma.jbs.2016.12.01.13.

[29] D. Desai, "A Study on Linkage Between Job Satisfaction and Employee Retention," Int. J. Res. Appl. Sci. Eng. Technol., vol. 6, no. 6, pp. 588-593, 2018, doi: 10.22214/ijraset.2018.6092.

[30] A. Zanabazar and S. Jigjiddorj, "Impact of Employees Satisfaction in Employee Loyalty, Retention and Organizational Performance," Int. J. Manag. Appl. Sci., vol. 4, no. 7, pp. 51-55, 2018.

[31] M. Jamal and V. V. Baba, "Shiftwork and Department-type Related to Job Stress, Work Attitudes and Behavioral Intentions: A Study of Nurses," J. Organ. Behav., vol. 13, no. 5, pp. 449-464, 1992, doi: 10.1002/job.4030130503.

[32] O. Pasha, T. H. Poister, B. E. Wright, and J. Thomas, "Transformational Leadership and Mission Valence of Employees: The Varying Effects by Organizational Level," Public Perform. Manag. Rev., vol. 40, no. 4, pp. 722-740, 2017, doi: 10.1080/15309576.2017.1335220.

[33] Ö. Özer, Ö. Uğurluoğlu, G. Şantaş, and K. Avcı, "A Study on Toxic Leadership Perceptions of Health Workers," Glob. Bus. Manag. Res. An Int. J., vol. 9, no. 1, pp. 12-23, 2017.

[34] M.-C. Chao, R.-C. Jou, C.-C. Lioa, and C.-W. Kuo, "Workplace Stress, Job Satisfaction, Job Performance, and Turnover Intention of Health Care Workers in Rural Taiwan," Asia Pacific J. Public Heal., vol. 27, no. 2, 2015, doi: $10.1177 / 1010539513506604$.

[35] R. S. Biason, "The Effect of Job Satisfaction on Turn Over Intentions," Int. J. Econ. Commer. Manag., vol. 8, no. 3, pp. 405-413, 2020.

[36] J. F. Hair, B. Black, B. J. Babin, and R. E. Anderson, Multivariate Data Analysis: Global, 7th ed. Upper Saddle River, New Jersey: Pearson Education, 2011. 